| SBAD | Sosyal Bilimler Araştırmaları Dergisi

| JSRR | Social Sciences Researches Journal

(Yaz 2018) 13/1:123-140 / (Summer 2018) 13/1:123-140

Makale Geliş Tarihi: 27.02.2018 Yayın Kabul Tarihi: 31.05.2018

Doi Number :http:/ / dx.doi.org/10.19129/sbad.348

\title{
HAYAT GÜZELDİR ESERİ BAĞLAMINDA MUSTAFA KUTLU HİKÂYESİNDE KUŞ VE ÇIÇEK İMGESİ
}

Yaşar ŞİMŞEK **

Türk kültürü ve toplumunda geçmişten bugüne kuş ve çiçek önemli bir yer tutmaktadır. Eski Türk kültüründen/yaşantısından bugünün modern dünyasına kuşlar ve çiçekler insan hayatını etkileyen, kimi açılardan yönlendiren unsurlar olarak dikkat çekerler. Modern Türk hikâyeciliğinin önemli yazarlarından olan Mustafa Kutlu, kuşlara ve çiçeklere eserlerinde yer veren isimlerin başında gelmektedir. Kutlu, özellikle hayatı güzelleştirmesi ve insana yaşamın anlamını hatırlatması bakımından bu iki ögenin kullanımına sıklıkla başvurmaktadır. Bu makalede, Kutlu'nun Hayat Güzeldir eserinde yer alan kısa hikâyeleri, kuş ve çiçek imgesi etrafında incelenmiştir. Yazıda öncelikle imge, hikâyede imgenin kullanımı üzerinde durulmuş, kuşların ve çiçeklerin Türk kültürü ve edebiyatındaki yerine

Öz değinilmiştir. Daha sonra kuş ve çiçek imgesinin Kutlu'nun kalemine yansımalarına diğer eserlerini de kapsayan bir değerlendirme içinde yer verilmiştir. Ardından Hayat Güzeldir kitabındaki 21 kısa hikâye kuş ve çiçek imgesi etrafında incelenmiştir. Bu iki imgenin hikâyelerin aktarımına, bakış açısına katkısına değinilerek yazarın kuş ve çiçek ögelerine yer vermesinin nedenleri sorgulanmıştır. Temalar ve kişiler bağlamında bu iki imgenin kullanımları yorumlanmıştır. Hayat Güzeldir'deki kısa hikâyelerin geneline bakıldığında hem kuş hem de çiçek imgesinin yoğun bir şekilde kullanıldığını söylemek mümkündür. Yazar, özellikle insanın tabiatla ve hayvanlarla etkileşiminde kuşları ve çiçekleri öne çıkarmaktadır. $\mathrm{Bu}$ iki ögeye insan yaşamını güzelleştirmesi, iyi insan olmayı anımsatması ve incelikleri sezdirmesi bakımından imgesel yönüyle yer vermektedir.

Anahtar Kelimeler: Mustafa Kutlu, Hayat Güzeldir, hikâye, imge, kuş ve çiçek.

\section{THE IMAGE of BIRD and FLOWER in THE CONTEXT of THE HAYAT GUZELDIR in MUSTAFA KUTLU STORY}

Abstract

Bird and flower has an important place in Turkish culture and society from past to present. From the point of the ancient Turkish culture/living to contemporary world, birds and flowers draw attention in terms of affecting people life and guiding it. Mustafa Kutlu who is one of the significant authors of the modern Turkish story, is leading figure that gives place to birds and flowers in his works. Kutlu frequently resorts to this two element in terms of recalling the meaning of human life and

\footnotetext{
* Bu makale 21-22 Aralık 2017 tarihlerinde Yıldız Teknik Üniversitesi'nde düzenlenen IV. Yıldız Sosyal Bilimler Kongresi'nde sunulmuş bildirinin genişletilmiş ve yeni eklemelerle hazırlanmış hâlidir.

** Dr., Gaziosmanpaşa Üniversitesi, Eğitim Fakültesi, Türkçe ve Sosyal Bilimler Eğitimi Bölümü, e-ileti: yasar.simsek@gop.edu.tr. ORCID: 0000-0002-9389-4984
} 


\section{Yaşar ŞİMŞEK}

making the life beautiful. In this article, Kutlu examines the short stories of the book Hayat Guzeldir in the context of bird and flower. In this article, primarily the image and its usage is emphasized and the value of birds and flowers in Turkish culture is stated. Then, the reflection of birds and flowers' image to Kutlu's wording is included in an evaluation that comprises other works. After that, 21 short stories in Life is Beautiful are examined around bird and flower image. By putting emphasis on transfer of this two image, contribution to point of view, it is interrogated the reasons why the author gives place to bird and flower element. The usage of this two element is commented in the context of themes and characters. It is possible to say that both the bird and flower image is intensely used when looked at short stories in general. The author especially brings forward the flowers and birds in the interaction of human between nature and animals. He imaginatively gives places of this two element in terms of making human life beautiful, reminding of being good people and intuiting the elegance of life.

Key Words: Mustafa Kutlu, Hayat Guzeldir, story, image, bird and flower.

\section{Gíriş}

Sözlükte "zihinde tasarlanan ve gerçekleşmesi özlenen şey, hayal, hülya", "genel görünüş, izlenim, imaj" (TDK, 2011: 1182) karşılıkları verilen imge bakılan, görülen, duyulan ve hissedilen şeylerin insanda bıraktığı izler/yansımalar olarak açıklanabilir. Bir başka söylemle "İmge, fiziksel bir algılamanın ürettiği duyumun zihinde yeniden üretilmesidir" (Friedman, 2004: 80). İmge ve imgelem kişinin gördükleri karşısında beliren bir perde ve insanın algılarından arta kalan parçalar olarak tarif edilebilir. Aynı zamanda imgeyi "içimize özgü görüşün izleri" (Ponty, 2006: 37); "bir şeyin bilinci" (Sartre, 2009: 154); "anlam taşıyıcısı" (Batur, 2000: 71) olarak tanımlayanlar da vardır. Bunun yanı sira imge, okurun zihninde beliren bir görüntü, kavram, düşünce ve resim olarak da düşünülmüştür. Boynukara, 18. yüzyılda ortaya atılan imgelem kuramlarından birinin imgenin "görselleştirme yeteneği" olduğuna dayandırıldığını böylece edebiyatın "çoğu kez okuyucudaki görsel tepkileri geliştiren bir vasita olarak görüldü[ğünü]" (1997: 91) söyler. Öte yandan zihinde bir imgenin belirmesi, alg1 sonucunda oluşacağ1 gibi daha sonra bir algıyı düşünmek, çağrıştırmak ve bir şeyi zihinde kurmak yoluyla da olabilir (Cevizci, 2000: 235). Burnett ise imgelerin "etkileşimi, insanları ve paylaştıkları ortamları şekillendiren arayüzler" olduğunu belirterek yaşamın içindeki canlılığına işaret eder (2012: 25). Aynı zamanda imge ister görsel ya da yazınsal isterse yapıntısal olsun insanın dünyayı nasıl gördüğüyle ilgili olarak değerlendirilmektedir (Demiralp, 2004). Ramazan Korkmaz ise imge kavramını "gerçekliğin kaba ve ihlal edici kuşatmasından sıkılan ruhun; sonlu, sınırlı ve iğreti olandan; sonsuz, sınırsız ve aşkın olana açılması" (2002: 274) şeklinde tarif eder. İmge kullanımını ve imgesel yönelimleri "Nesnelleşmenin tüm duyuları felç eden ve derin anlamı yutan tek boyutlu gelişmeciliği, insanı, dondurulmuş/durağan söylemin kısırlığından kurtulmak için daima çareler aramaya sevk etmiştir... Bu yöneliş, dış dünyaya ait durağanlığın tepkisel itiliminden olduğu kadar, içimizdeki yaratıcı potansiyelin varoluşsal bir dizgede genişleyerek kendini gösterme arzusundan 
da izler taşır" (Korkmaz 2002: 274) diyerek açımlar. Bu anlamda imge, modern zamanlarda sanatçının tekdüze anlatımdan uzaklaşarak farklı, aşkın anlamlara ulaşımına olanak tanır.

Öte yandan "Sanat çabası her şeyden önce simge yaratma çabasıdır; sanat simgeyle başlar sanatın kökeninde simge vardır. Sanat yapıcı kendinden nice simge barındırır. Her yapıt bir simge değil bir simgeler bütünüdür" (Timuçin, 2003: 193). Bu anlamda edebiyat eserlerinde -şiir, hikâye, roman- imge, simge ve sembol kullanımları şairi/yazarı anlatacağı noktalar üzerinden derinleşmeye götürür, sanatçılar oluşturdukları sembollerle/imgelerle dış dünyanın görüntülerini okurların zihinlerine nakşederler. Yeni dünyaların, farklı hayatların kapılarını okura açarak düşünmelerine ve hissetmelerine olanak tanırlar. Okurlar böylelikle edebiyat metinlerinin art alanlarını daha iyi kavrayarak okudukları metinleri/eserleri daha bir anlamlandırma imkânı bulurlar. Çünkü "bir imgeyi yorumlamak yalnızca gördüğümüzü, düşündüğümüzü belirlemek değil, ona verilen anlamlar akıntısı boyunca yol almaktır" (Yücel, 2013: 12). Bu bağlamda Leppert'in imge üzerine söyledikleri ve imgeye yüklediği anlamı burada ayrıca belirtmek gerekir:

“İmgeler bize asıl dünyayı değil, dünyalardan bir dünya gösterir.

Gösterilen şeyler değil, bunların temsilleridir imgeler: Temsil, yani yeniden-sunum. Hakikaten, imgelerin temsil ettiği şeyler "gerçek" dünyada olmayabilir; sadece muhayyile, kuruntu, arzu, rüya ya da fantezi dünyasında var olabilir. Fakat tabii, öte yandan, dünyaya flu ya da bu şekilde dâhil olan bir nesne olarak vardır her imge. İster fotoğraf, ister film ya da video, isterse de resim olsun, imgelere baktığımızda gördüğümüz şey insan bilincinin ürünüdür. İnsan bilinci ise kültür ve tarihin ayrılmaz bir parçasıdır. Buradan şu sonuç çıkıyor: İmgeler, maden cevheri gibi kazılıp çıkarılan şeyler değil, belli bir sosyokültürel ortam içerisinde belli bir işlev görmesi için inşa edilen şeylerdir" (Leppert, 2009:

16).

$\mathrm{Bu}$ bakımdan sanat eserlerinde, edebiyat metinlerinde imge kullanımı kimi durumlarda mecaz, temsil, sembol, motif, metafor gibi anlatımdaki diğer kullanımlarla ilişkilendirilebilir. İmge, sanatçının eserinde estetik yaşantısını, kültürel eşiğini ve algısal düzeyini göstermesi açısından kıymetlidir. İmge kullanımına daha çok şiir türünde rastlanmasına karşılık masal, roman, hikâye gibi anlatma esasına bağlı türlerde de imgesel kullanımlarla karşılaşılmaktadır.

\section{İmge ve Hikâye}

Bir hikâye anlattığı konu, işlendiği tema kadar içerdiği imgelerin çeşitliliği ve zenginliğiyle de değerlendirilmektedir. Erendüz Atasü, 90'l y yllardan itibaren roman ve öykü özelinde edebiyat dünyasında imgeye bir yöneliş olduğunu belirterek bu türlerde imge kullanımının anlatımı şiir diline yaklaştırdığını söyler:

“Edebiyat imgeye yöneliyor... 'Simge'den, yani duyuları devre dışı bırakarak, zihnin mantıksal işleyişine, başka deyişle 'anlamak' edimine doğrudan uyarı gönderen 'sözcük'ten beş duyumuza seslenen 'imge'ye; sözcüklerin kurallarına uygun sıralanmasiyla kurulan temel tümceden ve

| Sosyal Bilimler Araştırmaları Dergisi 
metinsel anlatımdan, sözcüklerin etkileşimleriyle örülen 'imgesel anlatım'a yakınlaşıyor. Başka deyişle romanda ve öyküde kurgu ve anlatım şiirleşiyor" (2003: 11-12).

$\mathrm{Bu}$ anlamda son yıllarda imge kullanımı ve imgesel anlatım, hikâye türünün oluşum/yaratım sürecine etki ederek estetik bütünlüğe kavuşmasına katkıda bulunmuştur. "Zihni harekete geçiren bir unsur olan [s]imge, hikâyede kanitlardan ve açık hikâyelerden daha etkilidir" (Sağlık, 2003, 34). İmge veya sembolik kullanımlar hikâyede yaratılmaya çalışılan atmosferi destekler ve başından sonuna anlatının canlı kalmasını sağlar. Aynı zamanda kullanılan/oluşturulan imgeler okurun dikkatini öne çıkararak anlamsal düzeyde okurun metinle bütünleşmesine imkân sağlar. Rasim Özdenören'in Nathalie Sarraute'un "Çocukluk" adını taşıyan anlatısından hareketle belirttiği gibi bir anlatıda/hikâyede "anlatıcının, (...) belli bir izlenimini dile getirirken, o izlenimin, onun kafasında belli bir imge ile canlandığını" ve sonra o imgenin çeşitli kavram ve sözcüklerle dile getirilmeye çalışıldığını (2011: 26) söylemek mümkündür. İşlenen temaların sunumunda ve hikâye kişilerinin psikolojik tutumlarının yansıtılmasında imgeler öne çıkar. İmgesel kullanımlar, hikâyelerde işlenen değerlerin görüntü seviyelerini insanlığın anımsamasına katkıda bulunarak bir nevi yazarın yarattığı dünyanın sezilmesine yardımcı olur. Bir başka ifadeyle "Sembol dilinin zenginliğini eserlerinde kullanan yazarlar, bu kaynaktan, karakterleri tanitmak, tema, zaman ve mekân gibi unsurlara açıklık kazandırmak ve anlatımı etkili kılmak için yararlanmışlardır. Semboller kimi eserlerde kişinin bilinçaltını ve komplekslerini yansıtan rüya ve arketiplerin içine gizlenerek karşımıza çıkarken, kimi eserlerde de sembolik anlam taşıyan mekân, zaman, kişi, renk, şekil ve sayı olarak entrik kurguyu şekillendirirler" (Yılmaz, 2011). İzlenimlerin aktarımı bir nevi imgeler vasitasıyla mümkün olur ve yazar da hikâyesini yarattığı imgeler üzerinden kurgular/inşa eder. $\mathrm{Bu}$ imgelerin çeşitli sözcüklerle, kavramlarla, nesne ve varlıklarla oluşturulmaya/yaratılmaya çalışıldığı bir gerçektir.

Değişen zaman ve tekniklerle birlikte hikâyede kullanılan imgeler, bireyin modern dünyada içinde bulunduğu çağdaki bunalımını, sıkıştırılmışlığını, yalnızlığını başka bir dünyaya çeviren unsurlar olarak öne çıkar. Zira imgecilik, Eliot'un sanatta duygunun sadece nesneler yoluyla ifade edilebileceği görüşünün doğrudan bir sonucu olarak değerlendirilmektedir (Boynukara, 1997: 95). Bununla birlikte bir öyküde gösterilen şey, anlamını insanın birikiminden, geleneklerden ve kültürden alır ve bu anlamıla imge insana aittir; özne merkezlidir (Şakar, 2012: 17). Hikâyede imge kullanımı da bu tür ögelerin insanla ve insana özgü olgularla ilişkilendirilmesiyle mümkün olur. Duyular bilhassa görme duyusu, kişinin hayal gücü, imgelemem dünyası, çağrışım yeteneği ve kişisel birikimi öyküde imgenin kullanılmasında önemli bir işleve sahiptir. Bu bağlamda Emel Aydın Özer'in imgenin hikâyede/öyküde kullanımı ve değeriyle ilgili söylemleri önem taşımaktadır:

“İmgelerin öyküde yer almasında model alınan, dış dünyaya bağlı olaylar değil; o olayların insanlar üzerinde bıraktığı intibalar olur. Yani imgeler, yaşananların sebep olduğu hâlleri, bıraktığı izleri ifade eder. Böylece daha 
üst seviyede bir anlatım/ söylem ortaya çıkar. Bu durum, şiirde olduğu gibi öyküde de yüzeyselin yanında derin okumalar yapılması ihtiyacını doğurur. Şiirden alınan bu özellik, öyküden her okunuşta daha farklı ve daha derin anlamlar çıkmasını sağlar." (Aydın Özer, 2014).

\section{Kuş ve Çiçek İmgesi Üzerine}

Türk kültüründe azımsanmayacak bir değere sahip olan kuş ve çiçek, Türk edebiyatında da geçmişten bugüne metafor, motif, imge, tema, şahıs ve varlık düzleminde yer bulmuştur. Bu varlıklar çağrıştırdıkları kavramlar, yansıttıkları değerler, estetik ifade kalıpları ve anlam derinlikleri açısından edebî türlerde ve sanatçıların anlatı evrenlerinde öne çıkmaktadırlar. Aynı zamanda kuş ve çiçek imgesi hayatın güzelliklerini, yaşamın canlılığını ve insanın dünyaya olumlu bakış açısını yansıtması açısından edebiyat türleri için bir alımlama eşiği oluşturmaktadır. Geçmişten bugüne sanatçıların aktarımını, üslubunu ve dil kullanımını çevreleyen kuş ve çiçek kavramları özellikle yazınsal anlatım türleri için sembolik ve imgesel bir unsur olarak değerlendirilmektedir. Kadim Türk kültürü içinde çeşitli anlamlara bürünerek bugünün modernizme evrilen dünyasında kuş ve çiçek, insan yaşamındaki kısa çizgide daha ziyade olumlu anlamda etken/yardımcı figürler/varlıklar olarak yer almaktadirlar.

Tabiatla iç içe yaşayan Türklerin yaşantısındaki kuşlara ve çiçeklere özgü duyarlılık hâliyle edebiyatlarına yansımıştır. Bu anlamda Türk edebiyatında pastoral ögeler/unsurlar içinde kuş ve çiçek, öteden beri sıkça kullanılan/işlenen motifler, imgeler olarak öne çıkmıştır. Özellikle hem Klasik Türk edebiyatında hem de Türk Halk edebiyatında -daha çok şiir türünde- kuş ve çiçek odaklı pastoral ögelerle ilgili kullanımlara, göndermelere rastlanmaktadır. Bu varlıklar içinde kuş sadece yaşayan bir canlı olarak değil, geleneksel bağlamda bir değer ve sembol hâline dönüşmüştür. Anlam yönü itibarıyla kuş gurbetin, sılanın, beklentinin, acının, yaşamın, ölümün, özgürlügüun, inceliğin, güçsüzlüğün simgesi olmuştur. Kuş bir tarafta sevginin, zarafetin, samimi duyguların sembolik anlamda karşılığını ifade ederken, diğer tarafta kudretin ve gücün timsali kabul edilmiştir. Bununla beraber geleneksel hayat anlayış1 çevresinde güçsüzlükleri, kırılganlıkları dolayısıyla ruhların teslimiyetinde de kuş motifinden sıkça yararlanılmıştır.

Türk edebiyatı bağlamında düşünüldüğünde çiçek imgesine/motifine en az kuş kadar yer verildiği görülmektedir. Özellikle İslam ve Türk kültüründe çiçek önemli bir yere sahip olup sembolik anlamda pek çok değeri ihtiva eder. Medeniyetin önemli olgularından olan çiçek geleneksel anlamda Türklerde en başta sevginin dili olmuştur. Başta sözlü verimlere -türkülere, manilere, ninnilere- konu olan çiçek, halk edebiyatı türlerinde ana örgelerden biri kabul edilir. Bu anlamda halk kültürünün oluşturulmasına katkıda bulunan âşıkların/ozanların dilinde çiçek imgesi vazgeçilmez bir unsur olarak belirir. Yâri, sevgiliyi, aşkı çağrıştıran çiçek bir nevi sevginin sembolik anlamda ifade edilişidir. Aşk ve sevgi bağlamında düşünüldüğü gibi dinî-tasavvufî anlamda da yeri olan çiçek motifi, kutsallığı açısından imgesel özellikleriyle kullanılmıştır. Bu anlamda Klasik şiirde çiçek imgesi birçok yönüyle Divan şairlerinin eserlerini süslemiştir. Beşir Ayvazoğlu Güller Kitabı eserinde Türk kültüründe

| Sosyal Bilimler Araştırmaları Dergisi 
çiçeklerin anlamlarını açıklayıp onlarla ilgili anlatılan efsanelere yer vererek çiçeğin önemini ortaya koyar. Çiçeğin sadece dağları, kırları, bahçeleri süsleyen bir bitki olmadığını hayatın her aşamasında insana eşlik eden onun yaşamını güzelleştiren ve süsleyen bir unsur olduğunu dile getirir (1997: 20). Ayvazoğlu, incelemesinde özel ve seçkin bir konuma sahip olan gülün farklı kültürlerde taşıdığı anlamina ve önemine değinerek onun sanatçılar/şairler için üzerinde mutabık kalınan tek çiçek olduğunu söyler.

Genel itibariyle Türklerin öteden beri farklı sanat dallarında işledikleri çiçek ve kuş imgeleri/motifleri aynı şekilde halk kültüründe ve yaşamında doğaya ait canlılar/varlıklar olmaları hasebiyle de kıymetlidirler. Kuşlar ve çiçekler imgelem düzeyinde halkın geleneksel el sanatlarından sözlü kültürüne, yazılı edebiyatından sosyal yaşamina değgin geniş bir çekim gücüne sahiptir. Orta Asya'dan Anadolu'ya uzanan geniş coğrafyada da sembolik anlamda ve çeşitli açılardan işaret dili olarak kullanılmıştır. Çiçek ve kuş imgesi, halk hikâye geleneğinden bugünün modern hikâyeciliğine uzanan süreçte kullanılan unsurların da başında gelir. Pastoral duyarlılık taşıyan, tabiatı seven ve yaşamın gizemini doğada/dış mekânlarda arayan yazarlarda kuş ve çiçek imgesinin kullanımına sıkça rastlanır. Modern hikâye denildiği zaman ilk akla gelen isimlerden olan Sait Faik' te yaşama sevinci ve hayatın güzellikleri kuşlar, çiçekler etrafında aktarılır. Yazarın "Son Kuşlar" hikâyesi bu anlamda dikkati çekmektedir. Sait Faik bu hikâyesinde, vaktiyle küme küme adaya uğrayan ve cıvıltılarıyla adayı şenlendiren kuşların kayboluşunu, onları yakalayıp avlayan zahire tüccarı Konstantin üzerinden sorgular. Okura kuş imgesi (imajı) üzerinden insanın gitgide doğaya yabancılaşmasına ve zarar vermesine eleştiri getirir. Doğanın ve doğadaki canlıların/varlıkların tahrip edilmesiyle gelecek kuşakların yaşamının tehlikede olduğu mesajını verir (2002: 12-13). Tabiatla, çiçeklerle ve kuşlarla ilgili benzer duyarlılık Sabahattin Ali hikâyelerinde de görülmektedir. Yazar, özellikle kötülükler karşısında insanı tabiatın güzelliklerine yöneltir, onlar üzerinden insanda sevme, merhamet, vicdan ve iyilik duygularını açı̆̆a çıkarır. Örneğin yazar, "Kırlangıçlar" hikâyesinde kuş imgesi çevresinde sevginin yüceliği üzerinde durarak kuş temsilleriyle insanlığa bir mesaj vermeye çalışır (Ali 2015: 38-41) Özetle Türk hikâyesinde kuşlar ve çiçekler iyilik, güzellik, kaçış, özgürlük, naiflik, zarafet, hüzün gibi kavram ve değerler çevresinde işlenir. Kimi zaman bir sığınak ve tutamak olur kimi zaman da insanı huzurlu kılan bir etmene dönüşür.

Bugünün sanat anlayışında ise kuş ve çiçek imgesi daha çok geleneksel olanla modernizmin mukayesesinin yansıtılmasında geleneğin/eskinin, eski değerlerin yeni hayatın değer yargılarıyla karşılaştırılması bağlamında kullanılır. İki unsur/varlık modern hayatta ve bireyin yalnızlaşan dünyasında bir ş̧ık ve huzur kaynağ düşünülür. $\mathrm{Bu}$ ögeler farklı anlamlar yüklenerek modern edebiyatta toplumların kaybolmaya yüz tutmuş değerlerini, unutulan alışkınlıklarını, boğucu yaşantılarını çevreleyerek bireyin hayata bakışını olumlar. Ponty'nin "algılanan dünyayı bulgulama" bağlamında ifadelendirdiği gibi insanları şeylerle/nesnelerle olan ilişkileri mesafeli ve tarafsız olmayıp tam tersine onlarla karışan ve âdeta onlara insani 
özellikler yükleyerek yaşam alanlarına katan bir niteliği/formu vardır. Kuşlar ve çiçekler de bu niteliğiyle modern dünyada insanın hayatını sarmalar. Ponty, bu dünyada insanın yalnız olmadığını kendilerine hayvanların da katıldığı ve tüm ötekilerle birlikte var olduklarını yaşamın erdemine dikkat çekerek belirtirken insan yaşamının diğer canlılar, varlıklar ve nesnelerle çevrelendiğine işaret eder (2010: 36). $\mathrm{Bu}$ görüşler çevresinde kuşların ve çiçeklerin yaşanan dünyada insan hayatını anlamlandıran, kimi yönlerden çevreleyen ve duyusal anlamda bireyin değer arayışına yön veren varlıklar olduğu söylenebilir. Gerçek dünyada bu varlıkların olumsuz niteliklere sahip türlerine rastlansa da edebiyat metinlerinde daha çok güzelliklerin, iyiliklerin, sevinçlerin yansıtılması ve yaşatılması bakımından bu iki varlığa yer verildiği görülür. Kısacası bu varlıklar, çeşitli anlamlara ve imgelere bürünerek edebiyat eserlerinde imaj, sembol, motif ve temsil olarak işlenirler.

\section{Kutlu Hikâyesinde Kuş ve Çiçek İmgesi Üzerine Notlar}

Sanatçı her şeyden önce yaşadığı çağa ayna tutan insandır. Sanatçının eserinde okur kendi yüzünü, kendi kişiliğini görür. Türk edebiyatının güzide hikâyecilerinden Mustafa Kutlu da, 1970'ten beri Türk toplumundaki değişimleri/dönüşümleri, modern hayatın yansımalarını, insanın yoksulluğunu, kırılmalarını ve sancılarını yansıtan bir ayna olmuştur. Aynı zamanda yazar bireyin huzurlu iç dünyasını, samimiyetini ve inceliğini eserlerinde öne çıkaran bir isim olarak dikkat çeker. Ömer Lekesiz'in deyişiyle "Mustafa Kutlu öyküsünün hemen hepsinde, yazmaya, hatta yazarın kültürel ve düşünsel dokusunu oluşturan okumalarının ve toplumsal ve siyasal ilişkilerinin başladığ1 yıllardan günümüze kadar ülkemizin ve insanımızın yaşadığ1 yaklaşık yarım yüzyıllık maceranın toplumsal, siyasal, kültürel ve insanî boyutlarını en çıplak hâliyle ve öyküsel-kurgusal gerçekliğiyle görürüz" (2001: 116). Bu anlamda Kutlu hikâyesinde yer yer imgesel, sembolik ve temsili anlatımlar göze çarpar. Yazar, hikâyelerine verdiği isimlerde dahi simgesel bir dil kullandığı gibi hikâyelerinde yer verdiği kavramları, nesneleri, varlıkları da kimi zaman belli bir imgelem içinde işler.

Mustafa Kutlu'da imgeler, anlatıma estetik duyuş kazandıran, akıcılık sağlayan ve edebi değerini güçlendiren özellikleriyle belirir. Kutlu, kimi hikâyelerinde kendini kolay ele vermeyen, derinlikli ve çok katmanlı metinler oluştururken imgelere başvurur. Düşünsel arka planı olan, dine/mistisizme yaslanan hikâyelerinde de zaman zaman dilin imkânlarını genişleten imgeler kullanır. Yazar, hikâyelerinde kimi zaman bir sırrı açığa çıkarırcasına anlamı çeşitli semboller üzerinden okurun dikkatine sunarak sezdirme yolunu seçer. Kavramlara, olgulara yüklediği anlamları imgeler vasıtasıyla açıklamaya ve örneklendirmeye çalışır. Bu yönüyle imge yazarın dili kullanma başarısını ve yetkinliğini gösteren bir unsura dönüşür. İmgeler vasıtasıyla estetik seviyeyi yükselten yazar, sıkı anlam örgüsüyle ve farklı kurgusal düzlemiyle de dikkat çekmektedir. Diğer bir ifadeyle "Kutlu hikâyesinin anlatım özelliklerinin en başında gelen bu sembolik, imgesel yapı onun daha çok çağrışımlar ve sezgilere yol verdiğini gösterirken, aynı zamanda da okurun dikkatini yoklayan, onun okuma biçimine güvenen bir düzeneği de imlemektedir" (Yıldırım, 2007: 191).

Kutlu, hikâyelerinde kahramanlarının ifade edemediği, anlamlandıramadığ 1 olayları, durumları çeşitli motifler, temsiller ve imgeler vasıtasıyla açıklamaktadır.

| Sosyal Bilimler Araştırmaları Dergisi 


\section{Yaşar ŞİMŞEK}

Pastoral ögeleri sıkça kullanan, bu eğilimiyle Türk hikâyeciliğinde öne çıkan Kutlu, kır hayatından tabiatın güzelliklerine, doğaya dair betimlemelerden içinde yaşayan canlıların özelliklerine kadar pek çok şeyi hikâyelerinde yansıtır. Kıra, köye, taşra hayatına dair izlenimlere, insanların bu mekânlardaki konumlarına ve tabiatla olan sıkı ilişkilerine yer verir. Şehir hayatının bunaltıcılığından, sıkıcılığından kır hayatının güzelliklerine, doğal varlıklara ve tabiattaki yaşantılara sığınarak kurtulmayı düşler. Yazarın sığındığı bu güzelliklerin, varlıkların başında da kuşlar, çiçekler ve onlarla ilgili hususiyetler gelir. Necip Tosun da onun hikâyelerinin tabiatla, tabiata ait unsur ve varlıklarla iç içe oluşuna şöyle dikkat çeker:

"Kutlu'nun öykülerinin odağında 'tabiat' vardır. Ve tabiat, onun öykülerinin bir uvertürü, bir yan öğesi olmaktan çok, aslî unsuru, öznesi, kahramanıdır. Kutlu, söyleyeceği pek çok şeyi tabiatın diliyle izah eder. Benzetmeleri, yakıştırmaları, örnekleri hep tabiattan seçer. Ona göre güzellik, masumiyet, sadelik sadece ve sadece tabiattadır. Günümüz insanının yaşadığı kaotik ortamdan kurtulacağı yegâne sığınak tabiattır. Çünkü insan ve tabiat birbirlerini tamamlayan iki dosttur. Ve tabiat gönlünü hesapsız, kitapsız insana açar. İnsan tabiattan uzaklaştıkça, onu yok saydıkça, kendinden de uzaklaşır" (2004: 61).

Mustafa Kutlu, kurduğu olay örgüsünü, konuşturduğu kişileri, işlediği temaları anlatım/aktarım bağlamında çoğu hikâyesinde kuş ve çiçek temsillerine, motiflerine, imgelerine yer verir. Özellikle eserlerde farklı türleriyle, çeşit çeşit isimleriyle yer alan kuşlar ve çiçekler Kutlu hikâyesinin imgesel yönünü, sembolik değerini ve dil zenginliğini de yansıtır. Yazarın zarif, sevecen, merhametli bakış açısını bu iki kavramın anlam değeri üzerinden oluşturduğu söylenebilir. Kutlu, her ne kadar görece olarak okunması kolay hikâyeler yazsa da eserlerinde zengin çağrışımlara sıklıkla yer vermektedir. Daha çok kişisel duygulanımlar, durumlar ve izlenimler üzerinden kurgulanan bu hikâyelerinde yazar, kimi zaman anlatıdan, kurmacadan uzaklaşarak deneme ve şiir diline yaklaşır, türler arası geçişlere yer vererek yoğun anlam değeri taşıyan söylemlerle metinlerini oluşturur. Yazarın imgesel anlatımın yanında bazen motifler, temsiller üzerinden kapalı anlamlara ve farklı anlatım biçimlerine başvurarak sıkça kullandığı kuş, çiçek kavramlarının anlam değeriyle hikâyelerini edebî ve estetik anlamda zenginleştirdiği söylenebilir.

Hikâyelerde karakteristik bir özellik olarak beliren kuş ve çiçek temsillerinin kullanımıyla yazar, gerek gelenek-modern, eski-yeni, köy-şehir ilişkileri gerekse iyikötü, güzel-çirkin, saadet-keder gibi hayatın içimdeki zıtlıkları ortaya koymak ister.

Onun kahramanları yaşadıkları modern/şehir hayat(ın)ın kıskacından kır/köy/geleneksel hayatının, tabiatın ve tabiata ait varlıkların dinginliği, güzelliği, içtenliği ve sesleriyle uzaklaşmaya çalışır. Örneğin bir kuş cıvıltısının neyi anlattığıyla/anımsattığıyla ilgili olarak yazar şunları kaydeder:

"Bir kuş cıvıltısı bize neyi anlatır? Herhâlde topraktan geldiğimizi. Ağaçtan, yapraktan, tohumdan, çiçekten, meyveden, sudan, dağdan, denizden, buluttan, havandan, yağmurdan, böcekten, kırdan, bayırdan, 
Âdem atamızdan geldiğimizi. Nerede durduğumuzu sarsılarak hatırlarız. Bir kuşun bir kuşa seslenişinde, patlayan tomurcuğun güneşe gülümseyişinde, yağmurun toprağa değişinde varolan sırrın şahidiyiz" (Kutlu, 1999).

$\mathrm{Bu}$ sözlerden anlaşılacağ 1 üzere Mustafa Kutlu'nun eserlerinde kuş ve çiçek imgesine yer vermesi, aynı zamanda yazarın dünya görüşü, hayat algısı ve sanat anlayışıyla ilişkili bir durumdur. Eserlerini genel itibarılyla geleneksel, dinî-mistik bir duyarlılık içinde kurgulayan, merhametli ve vicdanlı olmayı önceleyen yazarın, kuş ve çiçek imgesiyle bu duyarlılığına sembolik anlamda bir nitelik kazandırma gayreti içinde olduğu düşünülebilir. Kuşlara, çiçeklere farklı anlamlar yükleyen Kutlu, olay örgüsünü oluştururken, metinlerini kurgularken, durumların sebep-sonuç ilişkilerini, nedensellikleri sorgularken bu imgelerin geniş anlam değerinden olabildiğince yararlanır. Yazar, dile getirmek isteği hususların temel bağlamlarını kuşlar ve çiçekler aracilığıla okura sunmakta bu iki imge hikâyelerinin anlam yönünü kuvvetlendiren önemli bir metafora/sembole dönüşmektedir. Bu anlamda yazar, hikâyelerini oluştururken kimi zaman sahip olduğu dünya görüşünü, dinî duyarlılı̆̆ını ve geleneğe bağllığını bu iki varlık çevresinde yansıtmaktadır. Hikâye karakterlerinin sunumunda da kuş ve çiçek motifleri belirleyici bir rol oynar. Kişilerin acıma, sevinme, üzülme gibi duygulanımları kuş ve çiçek temsilleri ve imgeleri çevresinde verilir.

Geçmişte geleneksel ve dinî hayattaki kimi duyarlılıkların ifadesi/temsili olan kuşlar ve çiçekler, Kutlu hikâyeleri için bir imgelem dünyasına dönüşür. Modern dünyanın, şehirleşmenin, yabancılaşmanın getirmiş olduğu yeni hayat düzenine ve kentleşmeden duyulan hoşnutsuzluğun ayyuka çıktı̆̆ı bugünlerde Kutlu, doğaya ait kuş ve çiçek unsurlarını kullanarak âdeta başkaldırmaktadır. Manevi anlamda da bu iki ögeye anlamlar yükleyen yazar, hikâyelerinde güzelliğin, hoşluğun, inceliğin, merhametin, samimiyetin ve vicdanl olmanın ifadesi olarak bu iki motifi kullanmaktadır. Bu imgelerin yarattı̆̆ı değerler etrafında sembolik bir mesaj vermektedir. Bu anlamda Halime Yücel' in "imgenin anlatımı duygulara seslenir, temel olarak estetiğge, görme zevkine, algılama coşkusuna dayanır" (Yücel, 2013: 42) belirlemesi Kutlu'daki kuş ve çiçek imgesinin kullanımını çevrelemektedir.

Modern dünya içerisinde kimi zaman hikmetli yolların, insanca yaşamanın tarifini veren Kutlu hikâyelerinde kuşun ve çiçeğin sembolik anlamının sorgulanması bu açıdan önemlidir. Mehmet Kaplan, çiçek imgesinin kullanımıyla ilgili olarak yazarın "Eşik" hikâyesinde bir tür çöplüğü andıran ihale dairesi içinde mekâna yerleştirdiği yediveren gülünün dairedeki "bu pisliğe yabancı bir güzelliği temsil" ettiğini belirtir (1997: 373). Ayrıca yazarın, eşya ve insanların özelliklerini belirtmek için dili çeşitli imgeler vasıtasıyla kullandığını söyler. Bu bağlamda Kaplan'ın da ifade ettiği gibi yazarın pek çok hikâyesinde geçen kuşlar ve çiçekler modern zamanların düzensizliğine, pisliğine, kötülüğüne, çirkinliğine karşı duran hem gerçek hem de sembolik varlıklar olarak dikkat çekerler. Yazarın bir başka hikâyesi Yoksulluk İçimizde'de Süheyla'nın nişanlısı Engin'i buluşmalarında kendisine çiçek getirmemesine ve kanarya kuşunu sevmemesine rağmen onu sevdiği vurgulanır. Süheyla, Engin'in maddi hırslarını, zenginlik heveslerini hiçbir zaman

| Sosyal Bilimler Araştırmaları Dergisi 


\section{Yaşar ŞİMŞEK}

anlamlandıramaz ve yazar maddiyata önem vermeyen genç kızın ruhsal olanın ve güzelliklerinin peşinde oluşunu kuş ve çiçek imgesiyle yansıtır: "Yuvasına dönen kuş. Engin ona çiçek getirmemişti. Besbelli kanarya da sevmiyordu. Kanlıca sırtlarında küçük bir ev. 'Sevgiler soyut değildir' demişti. Nasıl bir laf. Mavi mavi bakan gözlerine dalmıştı. Kelimeler, özge manalar" (Kutlu, 2016: 23). Söz konusu hikâyede bir süre sonra Engin'in Süheyla'yı terk edip zengin bir kızla evlenmesi de, başlangıçta sevdiği kıza çiçek almayan, kuşları sevmeyen bir adamdan beklenen bir davranış gibi hissettirilir. Yazarın Mavi Kuş (2002) eseri de isminin imgesel/sembolik bir değer taşıdığ1 bir hikâyedir. Bir otobüse ad olan "Mavi Kuş", hem otobüs sahibi hem de kasaba halkı için maddi ve manevi öneme sahiptir. Otobüse verilen "mavi kuş" adının simgesel bir değeri vardır ve hayata dair güzel şeyler için bir gösteren konumundadır. Necip Tosun, Kutlu hikâyelerinde "dilsiz sandığımız, hissetmez, duymaz sandığımız bitkilerin, nesnelerin, hayvanların da tıpkı insanlar gibi duyduğunu, üzüldüğünü, sevindiğini, giderek bir ruhları olduklarını görürüz. Onların tabiatta, insanların yanında bir dekor, bir ayrıntı olmaktan öte, insanlarla aynı haklara ve benzer fonksiyonlara sahip bir 'kahraman' olduklarına ve insanlarla aynı kaderi yaşadıklarına şahit oluruz" (2004: 662) demek suretiyle kuşların ve çiçeklerin sıradan bir şekilde değil de aksine düşünülerek, bir duyarlılığı, bir farkındalığı göstermek/sağlamak adına metinlere yerleştirildiğine vurgu yapar. Bu bakımdan Mustafa Kutlu ilk eserlerinden itibaren sık sık yer verdiği kuş ve çiçek kavramları, yazarın anlatımını farklılaştıran ve metinlerinin anlamını derinleştiren bir sembole/imgeye dönüşmüş denebilir. Bu anlamda 1970 sonrası Türk hikâyeciliğinin etkin kalemlerinden olan Kutlu'nun eserlerinde doğaya/hayata ait başat imgeler arasında kuşlar ve çiçekler öne çıkmaktadır.

\section{Hayat Güzeldir'de Kuş ve Çiçek İmgesi}

Hayat Güzeldir Mustafa Kutlu'nun kısa hikâyelerini ihtiva eden ve toplamda 21 hikâyenin yer aldığı bir eserdir. Kitaptaki hikâyeler adından da anlaşılabileceği gibi hayatın güzelliklerini, 1şıltısını, sevincini yansıtan metinler olarak dikkat çekerler. Kitapta yer alan hikâyelerden ikisi dışında kuş ve çiçek imgesiyle ilgili farklı düzlemlerde dolaylı-dolaysız kullanımlara ve değinilere rastlanmaktadır. Aynı zamanda hikâyelerdeki betimlemelerde kuş ve çiçek imgeleri karşılıklı bir etkileşim içinde verilmiştir. Kutlu, "Profesyonel" ile "Yara" dışındaki bütün hikâyelerinde kuş ve çiçek imgesine motif, temsil ve anlam değeri açısından farklı bağlamlarda yer vermiştir. Aynı zamanda kitapta "Karga", "Kötü Bülbül” kuşları; "Çiçek Tefsiri", "Çiğdem Güzeli" de çiçekleri merkeze alan hikâye metinleri olarak yer ederler.

Kitabın ilk hikâyesi "Sevinç"te yazar hikâyeyi hayatın güzellikleri ve gündelik kaygılara dalmış insanların edimleriyle başlatırken kuş ve çiçekle ilgili temsili kullanımlara yer verir: "Bir parkta iki simitçi çocuk. Yan yana bir banka oturmuşlar. Etrafta çiçekler, kelebekler; çocukların elinden tutmuş gezdiren anneler, kalın mercekli gözlükleri ile gazeteye dalmış ihtiyarlar, binbir şamata ile birbirine sataşan, gülüşen mektep kaçkını öğrenciler, dilenciler, çöpçüler" (Kutlu, 2016: 7). Yazar, bu başlangıç cümleleriyle gündelik hayatın akışını öyküleme ve betimleme yöntemleriyle aktarırken 
kuşlara ve çiçeklere yaşama kattıkları olumlu özellikleriyle atıfta bulunur. Kuş ve çiçek imgesiyle yaşanan anın, geçen zamanın daha huzurlu bir görüntüye bürünmüş olduğu sezdirilir. Hikâyenin kahramanları iki simitçi çocuktur. Öğle yemeği için bölüştükleri simitten büyük parçayı kazanan çocuk bir türlü yiyemez, şans da olsa bunun arkadaşına yapılmış bir haksızlık olduğunu düşünür. Dayanamayıp fazla parçayı kopararak arkadaşına uzatır. Arkadaşı ise "Alamam", "O senin hakkın" deyince kararlı bir şekilde: "Olmaz, yiyemem, bölüşelim" der. Simitçi çocuklar, alırsın, almazsın diye çekişirken parkın uyanık güvercinleri hiç çekinmeden çocukların önlerine kadar gelerek dökülen susamlara dalarlar. Çocuklar da bu manzarayı görünce fazlalık olan parçayı birlikte güvercinlere doğrarlar. Önlerinde âdeta bir güvercin bahçesi oluşur. Çocuklardan biri çekinerek ayaklarına dolaşan kuşlardan birini okşar. Hayret, kaçmıyor diyerek şaşkınlıkla sevmeye devam eder. Onu gören diğer simitçi çocuk da güvercinleri sevmeye başlar. Çocuklar arada bir göz göze gelerek birbirlerine gülümserler. Etraflarında toplanan bu yüzsüz güvercinleri aç sandıklarından kalan simitlerini de önlerine doğrarlar. Kuşlar yedikçe çocuklar, sanki kendileri doyuyormuş gibi sevinirler. Yazar bu sahneyi "Güvercinlerin parlak tüylerinden geçen sevgi ve merhamet en saf hali ile çocuk kalplerini doldurmuştu (...) İkisi de sevincini bulmuştu. Artık ne açlık, ne tasa. Artık gidebilirler, yeniden satışa çıkabilirler. Her birinin etrafında yüzlerce Melek dolaşıyor. Elbette bütün simitleri satacak, cepleri para dolu olarak analarına koşacak, bu güvercin hikâyesini anlatacaklar." (Kutlu, 2016: 9-10) diyerek bitirir. Böylelikle hikâyedeki kuş temsili ve bu kavramm anlam değeri üzerinden çocukların en saf haliyle minik yüreklerini dolduran sevgiye, vicdanlı oluşlarına ve merhamet duygularına vurgu yapıldığı söylenebilir.

"Nöbetçi Âşık" hikâyesinde bir sınır karakolunda nöbet tutan bir askerin gece yarısı kulübede nöbet sırasında cüzdanından bin bir güçlükle çıkardığı nişanlısının fotoğrafına bakarken uğradığı silahlı bir saldırıdan bahsedilir. Genç asker, nişanlısının fotoğrafına bakmak isterken elinden düşürür. Fotoğrafı yerden almak için eğildiği sırada silahlı saldırıya uğrar. Bu durum nöbetçi aşığın hayatının kurtulmasına vesile olur. O andan itibaren nişanlısına artık bir can borcu olduğunu sayıklar. Ardından Nöbetçi Âşık'ın kahramanlığı sayesinde karakolun çevresindeki teröristler öldürülüp püskürtülür. Hikâyede silahların susma anı ve genç askerin korkusu "Nöbetçi orada, sırtı toprakta, yüzü karakola dönük yatarken nişanlısının hayali karakoldan çıkıp ağır ağır yaklaşıyor. Nöbetçinin kalbi kuş gibi çırpınıyor" (Kutlu, 2016: 14) şeklinde aktarılır. Yazar, kuş imgesi etrafında genç askerin ölüm korkusunu ve nişanlısını bir daha göremeyeceği düşüncesini kuşların savunmasızlığ1 ve zayıflığı üzerinden verir. Kuşların garipliği, kırılganlığı, üzerinden Nöbetçi Âşık'ın saldırı anındaki çaresizliği sezdirilir. Genç askerin nişanlısına olan aşkı, sevgisi ele alınırken nöbetçinin kalbinin çarpıntısı ile kuşun kanatlarını çırpması arasında ilişki kurularak benzetme yapılmıştır. Ayrıca gencin saldırı sonrası karakol komutanına saldırıla ilgili izahat verirken teröristleri nasıl öldürdügünü kendisinin anlamadığını belirtir ve yaşadıklarını "Sanki rüzgâr kalkanım, çiçekler miğferim, otlar siperim olmuştu. Kurşunlar sağımdan solumdan geçiyor ama bana değmiyordu" (Kutlu, 2016: 15) sözleriyle anlatır. Burada

| Sosyal Bilimler Araştırmaları Dergisi 
da yazar, çiçekler için miğfer benzetmesi yaparak genç delikanlıyı karakolun çevresini saran çiçeklerin korumasıyla ilgili bir imgelem kurmuştur.

Kiracı bir dükkân sahibinin hastaneden çıkışının anlatıldığı kitabın üçüncü hikâyesi "Çiçek Tefsiri" de ismiyle müsemma çiçek imgesi, motifi etrafında kurgulanmıştır. Hikâyenin başkişisi dükkân sahibi, hastaneden çıkıp caddeye doğru ilerledikçe şaşkınlık içinde her tarafta lalelerin açtığına şahit olur. Yürürken caddeyi ikiye bölen dar alanda çiçek cümbüşüne tesadüf eder. "Laleler, papatyalar, nergisler" arasından karşıya geçtiğinde de her yanda başka başka çiçeklerle karşılaşır. Çiçeklerden, çiçek kokularından kendini alamaz ve etraftan utanmasa eğilip yüzünü çiçeklere sürmek ister. Ardından utancını yenip yüzünü kaldırımın dibindeki lalelere sürer. "Sizi bana gönderen Rabbime şükürler olsun" diyerek dualar eder. "O esnada ne trafik gürültüsü, ne korna ne motor sesi. Çiçeklerin türküsüne kapilıp ilk gördüğü mescide kadar yür[ür]." (Kutlu, 2016: 18). Mescit çıkışı bugününe ve hâline şükrederek çınar dallarında cıvıldaşan kuşları dinler. "Ne güzel nefes almak. Şu çiçeklerin, kuşların arasında olmak" (Kutlu, 2016: 18) diyerek bir taksiye atlayıp dükkânına gider. Bu hikâyede kuş ve çiçek temsilleri çevresinde hastaneden çıkan hikâye kişisinin herhangi bir hastalığı olmadığını öğrenmesiyle hâline şükredişi, sevinç duyguları ve çiçekler ve kuşlar üzerinden anlatılır. Hikâye kişisinin korktuğu şeyin başına gelmediğinden dolayı gösterdiği yaşama sevinci kuş ve çiçek imgesiyle aktarılır. Yazar bir bakıma kuş ve çiçek imgesi kullanımıyla bu varlıkların insan hayatını güzelleştiren, olumlayan taraflarma vurgu yaparak bu olgularm insana iyi gelen yönüne göndermede bulunur. Hikâyenin sonunda da komşu esnafların gittikçe büyüdüğü günlerde dükkânı küçültmesinden yakınan oğluna "Sen bırak dükkânı, bir şey soracağım" diyerek "Laleler açmış, gördün mü?" (Kutlu, 2016: 21) demesi de çiçek imgesinin kullanımına örnek teşkil eder.

"Sırılsıklam" hikâyesinde aynı mahalleden olan ve aynı pasajda çalışan iki gencin (İrfan-Ebru) birbirini sevmelerinden bahsedilir. Yoksul ailelerden gelen gençlerin hayatın acımasızlığı karşısındaki dik duruşları ve bu güçlüğe beraberce karşı koyuşları "Âşık olan her zorluğa katlanır. El ele tutuştukları zaman zorluk falan kalmıyordu. Ağaçlar aniden yaprak açıyor, güller kokuyor, kuşlar cıvıldaşıyordu" (Kutlu, 2016: 31) cümleleriyle aktarılır. Yazar bu hikâyesinde gençlerin aşkını ve birbirlerine tutunmalarını güllerin kokusuyla, kuşların cıvıldamalarıyla özdeşleştirir. Kuş ve çiçek imgesi burada, gençlerin hayatındaki zorluklar karşısındaki birlikteliklerini, yaşama olumlu bakışlarını yansıtması bağlamında kullanılmıştır.

"Karga" hikâyesinde ise ağaçların henüz tomurcuklandığı bir zamanda kavak ağacına yuva yapmaya çalışan bir karga ailesinden bahsedilir. Kuşların kişileştirildiği ve kahraman olarak yer aldığı hikâyede anne-baba karganın yuvalarına nasıl şekil verdikleri anlatılır. Hikâyede yuvaya yerleştirilen yumurtalardan, yavru kargaların doğup büyümesinden, anne-babanın onlara uçmayı öğretmelerinden söz açılır. Son kısımda da bir genç kız gibi yavru kargaların yuvalarından uçup gitmeleri anlatılır (Kutlu, 2016: 35-40). Bu hikâyede yazar kargaların hayatıyla ve yuvalarıyla ilgili kesitler sunarken bu yaşamı insan hayatındaki benzerliklerle aktarır. Kuşlar ve insanlar 


\section{Hayat Güzeldir Eseri Bağlamında Mustafa Kutlu Hikâyesinde Kuş ve Çiçek İmgesi}

arasındaki benzerlikler kargaların insana özgü aile yaşantıları etrafında dikkate sunulur.

"Paranın Yükü" hikâyesinde ise oldukça zengin olan ve köşkte yaşayan Latif Bey'in bankada yüklü miktarda parası olduğundan bahsedilir. Yaşlı adam, ölüm gerçeğinin bilincinde olduğundan paranın kendisine yük olduğunu düşünür ve bu durum sebebiyle gün geçtikçe uykuları kaçmaya başlar. Latif Bey, kendisini huzursuz eden paradan kurtulmak için avukatını ve köşkte hizmetini gören Adil Efendi'yi yanına çağırır. Avukatına bütün parasını fakire fukara dağıtması için Adil Efendi'ye vereceğini belirterek kâhyasına da usulünce bu parayı nasıl dağıtacağını anlatır. Yazar anlatıcı Latif Bey'in üzerinden bu yükü atmasını "İş bitip, Adil efendi ile Avukat çıtıklarında, Latif Bey kendisini kuş gibi hafif hissetti. Sanki pencereden Boğaz'a doğru uçup gidecekti" (Kutlu, 2016: 44) şeklinde aktarır. Hayata, insanlığa karşı kendisini sorumlu gören Latif Bey'in bu büyük sıkıntısından kurtulması kuş temsili ve benzetmesiyle verilmiştir.

Bir trafik kazasının anlatıldığı "Hayat Güzeldir" hikâyesinde de kuş ve çiçek imgesi ve temsilleri hayatın güzellikleri bağlamında ele alınmıştır. Anlatıda arabası üç takla atan ve bayılan hikâye kahramanını, gözlerini açtığında bir gelincik çiçeği karşılar: "Gözlerini açtığında ilk gördüğü şey, arabanın açık camından neredeyse içeri girmeye çalışan bir gelincik oldu. Kırmızı, kocaman bir gelincik. Elinde olmaksızın o durumda gelinciğe gülümsedi" (Kutlu, 2016: 49-50). Kahraman ucuz atlattığını düşündüğü kaza sonrası gelinciğin kadife yapraklarına dokunur, "N'aber güzelim" diyerek onunla şakalaşır. "Sonra papatyaları, öteki kır çiçeklerini" fark edip kazanın olduğu çevrede arı ve kelebekleri görür. Hayatta kalmanın sevinciyle toprak ve tabiat ona bir başka güzel görünür. Yazar anlatıcı karakterin mutluluğunu etrafını saran kuş ve çiçekler üzerinden "Bahar patlamış, her yan yeşil. Başını kaldırınca şarampolün ortasında bir erik ağacı gördü. Her yanı bembeyaz çiçeğe kesmiş, sanki gelinlik giymiş. İnsan bakmaya doyamıyor. Onun üzerinde maçı gök ve bulutlar. Bir kuş öttü. Aynı kuş bir daha öttü. Tâ aşağılarda akan derenin şırıltısı duyuldu" (Kutlu, 2016: 51) cümleleriyle aktarır. Hikâyede kahramanın geçirdiği trafik kazası sonrası yaşıyor olmasının sevinci çiçek ve kuş temsilleri üzerinden anlatılırken hayatın güzellikleri de bu ögeler üzerinden sezdirilmiştir.

Kahramanlarının baba-oğul bülbül ve gül olduğu "Kötü Bülbül” hikâyesi ise kırgın bir aşk öyküsü etrafında dönmektedir. Aşk konusunda hayal kırıklı̆̆ı yaşayan baba bülbül, aşka inanması ve güllere kanmaması noktasında oğlu bülbüle bazı nasihatlerde bulunur. İroniye dayalı bir anlatımla aktarılan ve insani vasıfların yüklendiği bülbüller bir meyhanede içki ve sigara içerler. Gecenin sonunda bağ kenarına gidip bir kayanın tepesinde anne gülü ve onun kızı gülü kaçırmak için birlikte plan yaparlar. Ardından baba-oğul bülbüller, anne-kız gülleri yakalayıp kaçırırlar. Bu olaydan daha sonra "Bülbül' ün İntikamı" olarak bahsedilir (Kutlu, 2016: 57-59). Burada ironik bir üslupla ve hüzünlü bir edayla üzerinden gül ve bülbül arasındaki aşktan söz edilir. Hikâye imgesel bir değiniden ziyade kuş ve çiçeğin gül ve bülbül üzerinden temsili yönüyle değerlendirebilecek niteliktedir.

| Sosyal Bilimler Araştırmaları Dergisi 
Şifa verici özelliği olan bir çiçeğin anlatıldığı "Çiğdem Güzeli" hikâyesi de çiçek merkezli bir metindir. Hikâyenin kahramanın Ali, arkadaşlarıyla birlikte gittiği piknik dönüşünde bir çiçek bulur. Ali parlayan bu sarıçiğdeme âdeta vurulur. Onu israrla almak isteyen çocuklardan birine okunu ve yayını vererek çiçeği alır. Evine, annesine götürür. Annesi çiçeği görünce çok sevinir. Gözlerinden bir iki damla yaş dökülür. Ardından çiçeği ninesine gösterirler. Ninesi bunun adının "sarıçiğdem" olduğunu ve masalını da yatarken ona anlatacağını söyler. Babası da bunun bir dağ çiçeği olduğunu ve su vermemesi gerektiğini belirtir (Kutlu, 2016: 60-63). Ninesinin Ali'ye anlattığ1 "sarıçiğdem" masalında pek çok kuş ve çiçekten bahsedilir. Masalda amansız bir hastalığa düşen Hanım Sultan için yaşlı bir kadın, ismini hatırlamadığı ama sultanı iyileştirecek bir çiçekten söz açar. Bunun üzerine şehzade de sevgilisi için çiçeklerin padişahı gülden yardım ister. Gül de şehzadeye endişe etmemesini bütün çiçeklerin en kısa zaman sarayında olacağını söyler. Ardından da kuşlar, rüzgârlar, arılar, kelebekler ve bulutlarla bu haberi dünyanın bütün çiçeklerine duyurur. Turna, leylek gibi göçmen kuşlar uzaktakileri; serçe, güvercin, kumru gibi kuşlar da yakındaki çiçekleri gagalarıyla ve kanatlarıyla taşıyarak saraya bırakırlar. Saray kuş sesleri ve çiçek kokularıyla dolup taşar. Şehzade yaşlı kadının dediği gibi her gün bir çiçeği eşinin yarasına koyar. Ancak bir türlü şifa veren çiçeğe ulaşamaz. Sultanın iyice ağırlaştığı bir gece çiçeklerden biri kafasını çıkarıp sırrını açıklar. Sarıçiğdem adlı bu çiçek Şehzade'ye Sultan'ın yarasına beni koyun der. Şehzade bu isteği derhal yapar, sabahına Sultan iyileşip gözlerini açarken "Çiğdem Güzeli" adlı çiçek ise ölür. (Kutlu, 2016: 64-67). Kutlu bu hikâyesinde imgesel yönüyle olmasa da bir çiçeğin anlam değerine ve şifa verici yönüne değinerek kuş ve çiçek motifine yer vermiştir.

"Şafak Pembesi" hikâyesinde kocasını çok seven Saliha Kadın'ın Haşim Efendi öldükten sonra çok isteyeni olmasına rağmen ömründe kendisini incitmeyen kocasının üstüne gül koklamadığından bahsedilerek sevgili, yar, eş bağlamında çiçekle (gül) ilgili benzetme yapılmıştır (Kutlu, 201: 71). Yine hikâyede yaşlı kadın bir sabah, namazını kılıp tespihini çekerken evin bahçe kapısı alışılmadık bir şekilde vurulur. Terliklerini giyip bahçe kapısına doğru yürüyen Saliha Kadın garip bir hisse kapılır: "Tuhaf, havada bir gül kokusu var. Gül, zamanı değildi, hem bu koku gülden de öte idi. Tarçın mi, lavanta mi. Yok canım ne desen boş. Ama içler ferahlatan bir koku" (Kutlu, 2016: 73). Bu duygulanımlarla kapıyı açan yaşlı kadın bir ara kendisine seslenen sesin sahibini kapıda göremez. Çok sonra aklı başına gelir ve Hızır'ın evlerine uğradığını düşünür. Burada herkese yardım elini uzatan, insanları darlıktan esenliğe kavuşturan Hızır (as)'ın yaşlı kadının evine uğraması gül imgesi ve onun insan içini ferahlatan kokusu üzerinden ifadelendirilmiştir.

"Caney" hikâyesinde de kuş ve çiçek imgesi anlatımın estetik boyutunu oluşturması hasebiyle ve insan psikolojisine olumlu etkileriyle ele alınmıştır. Lodoslu ve üstüne üstlük güneşli bir havada serçelerin ağaçlarda cıvıldaştığ başlayan hikâyede kahraman anlatıcının tramvay camından gördükleri öyküleştirilmiştir. Hikâyede havanın o gün güzel ve güneşli olmasının herkesi mutlu ettiğinden söz açılır. Bu husus serçelerin de neşeli ötmelerine, cıvıldaşmalarına vesile 
olur. O gün diğer günlerden bir başka güzeldir, zira beklenen bahar gelmiştir. Kahraman anlatıcı tramvay camından dışarıya bakarken "Helva alın abilerim, helva alın teyzelerim, diye bülbül gibi şakımaya baş[layan]" (Kutlu, 2016, 78) bir çocuğa tesadüf eder. Burada çocuğun sevinçli sesi Türk edebiyatında özel bir yeri olan ve güzel sesiyle tanınan bülbülle özdeşleştirilir. Havanın güzelliği ve tabiatın canlılığ 1 karşısında mutlu olan çocuğun neşe içinde güzel sesiyle konuştuğu dile getirilir. Daha sonra kahraman anlatıcı alüminyum tepsideki bütün helvasını satıp bitiren çocuğu gözlemleyerek "Evet insanlarımız bu kadarcık olsun sevinmek, gülmek istiyorlar. Bir iyilik edip kalplerinde çırpınan kuşu sakinleştirmek istiyorlar" (Kutlu, 2016: 79) yorumunda bulunur. Böylelikle hikâyede insanların az da olsa mutlu olmak, sevinmek ve gülmek istediklerinden söz açılır. Küçük çocuk tepsideki helvalarını satınca sanki tüm sıkıntıları sona ermiş ve her şey yoluna girmiştir. Yazar, insanların kendilerine bir iyilik edip kalplerinde çaresizce, telaşlı bir şekilde çırpınan kuşu sakinleştirerek sıkıntılarına son verme arzularını kuş imgesi/metaforu üzerinden dile getirmiştir.

"Her Kuşun Bir Dalı Var" hikâyesinde içerikte her ne kadar kuş ve çiçek imgesiyle ilgili doğrudan bir değini olmasa da hikâye kişisi Sırrı'nın hüzünlü hayat öyküsü içinde tutunacak, sığınacak eş/arkadaş isteği her kuşun konabileceği bir dal olduğu benzetmesi/belirlemesi üzerinden verilir. Kutlu da, hikâyesine koyduğu 'Her Kuşun Bir Dalı Var' başlı̆̆ıly kuşlara özgü yuva olgusunu, insanlarla özdeşleştirmek suretiyle kuş temsiline ve imgesine yer vermiştir (Kutlu, 2016: 81).

"Rüzgârın Oğlu"nda atletizme meraklı olan ve ailesi şehre taşınınca simit satmaya başlayan hikâye kişisi Süleyman, gazetede koşu müsabakalarıyla ilgili bir ilan görür. Küçüklüğünden itibaren atletizm yarışmasına katılma hayali kuran genç, bu ilan metninin üzerinde, düzenleme kurulunda yer alan köylüsü bir adamın fotoğrafını da fark eder. Ardından onun yanına gidip yarışmaya katılmak için kaydını yaptırır. Yazar anlatıcı, Süleyman'ın akşam yemekten sonra ev halkına bütün olup bitenleri anlatmasıyla yoksul aile fertlerinin hepsinin içinde umudun kuşunun kanat çırpmaya başladığını aktarır (Kutlu, 2016: 106). Burada aile fertlerinin ertesi gün yarışmaya katılacak Süleyman'ın birinci geleceği yönündeki tasavvurları kuş benzetmesiyle belirtilmiştir.

"Sebebimsin" hikâyesinde ise İbrahim ve Ayşe zamanla birbirlerine derin bir aşkla bağlanırlar. İkisi de çok mutlu mesut günler geçirirler. Öyle ki dolaştıkları bir gün İbrahim, gölgesine sığındıkları ıhlamurun dalında öten Saka kuşunu Ayşe'ye tanitır. Âşıklar saka kuşunun kendileri için burada kalmış olabileceğini düşünürler (Kutlar, 2016: 119). Bu hikâyede saka kuşu, genç âşıkların sığındıkları ıhlamur ağacı altında onları bekleyen ve gençlerin birbirlerine olan sevgilerini simgeleyen bir varlık olarak işlenmiştir.

"Döne Döne" hikâyesinde ise atadan çiçekçi, gençliğinde hızlı yaşamış, hovarda ve kabadayı bir delikanlı olan Hacı'nın daha sonra bir mürşidin elinden tutmasıyla durulduğundan bahsedilir. Gençliğinde dedesi tarafından evden kovulan Hac1, mübarek bir zat olarak geri dönünce dedesi tarafından affedilmiştir. Yazar anlatıcı Hacı'nın babaevine dönüşünden sonra yaşadığı hayatı çiçeklerin anlam değerleri ve çağrışımları üzerinden anlatmıştır:

| Sosyal Bilimler Araştırmaları Dergisi 
“O günden sonra ömrünü karanfillerin, güllerin, sümbüllerin, papatyaların arasında geçirmiş. Babasını küçük yaşta kaybettiği için onu dedesi büyütmüş. Dede ölünce ailenin reisi Hacı olmuş. Bunlar kalabalık bir kabile. Hepsi de çiçekçi. Hacı, çiçeklerle düşe-kalka bir yüzlü bir çiçek olmuş anlayacağınız. Çiçek serasında yürürken şu gelen telefona, bu yardımın kendisine nasip olmasına şükretmeye başladı. (...) Bir gül, bir karanfil kokladı. Derken kalbi kabardı, çiçekler arasında ağlaya ağlaya semaya başladı. Yani bütün kâinat ile birlikte duaya sürdü. Yandıkça alevlendi, alev aldıkça dönmesi hızlandı. Siz çiçekleri ne sandınız. Onlar böyle bir ateşin yalazını görür de dayanabilirler mi?" (Kutlu, 2016: 127)

Hikâyede çiçeğin anlam değeri bakımından kişinin iyiye, güzele ve doğru olana yönelmesi dile getirilmiştir. Kahramanın eski-kötü yaşamını terk ederek çiçeklerin içinde âdeta melek gibi bir insana dönüşmesi çiçekler üzerinden ifade edilmiştir.

"Karpuz" hikâyesinde eve geç geldiği için babasından tokat yiyen Cemal, annesinin "oğlum çalışmış, para kazanmış üstelik bir karpuzla eve gelmiş" uyarısından sonra babasının şefkatine ve öpücüğüne mazhar olur. Anlatıcı, çocuğun heyecanını ve sevincini "Bu ilk sevgi seli Cemal'i de içine alıyor. Tokatı unutuyor. Ağzı rakı kokan bir baba. İçinde kuşlar uçuyor Cemal'in" (Kutlu, 2016: 135) şeklinde dile getirir. Yazar, babanın oğluna gösterdiği sevgi ve şefkat karşısındaki çocuğun mutluluğunu kuş metaforuyla ifade eder.

İstanbul' da geçen "Roman Havası"nda ise intihar etmek için Roma devrinden kalan kemerlerin üzerine çıan bir kadından bahsedilir. İtfaiye, polis ve insan kalabalığı arasında kadının bir ara sakinleşip oturduğundan ve sarı çiçeklerin yanına çökerek çiçekleri okşayıp içini onlara döktüğü anlatılır. Devamında da yazar anlatıcı, orada bir süre öylece kaldıktan sonra kadının artık direnmediğini ve sadece sarı çiçeklere odaklandığını, bazen de bakışlarından çiçeklere mi yoksa çocuklarına mı baktığının anlaşılamadığını dile getirir (Kutlu, 2016: 141). Burada ardındaki her şeyi bırakıp intihar etmek üzere olan kadın, sarı çiçekleri görünce sakinleşir ve intihar fikrinden vazgeçer. Bu bağlamda yazar, hikâyede çiçeğin insan üzerindeki olumlu etkisinden söz eder.

"Son İki Yaz" hikâyesinde ise İstanbul'da yaşayan ve şehrin kenar semtlerinin birinde kırk yıldır bakkallık yapan Osman Efendi'nin yalnız kaldığ çenesine koyarak dükkânın duvarındaki resme dalıp gittiği anlatılır. Osman Efendi duvardaki bu köy resmine bakarken kendi köyünü düşünür ve "Ellerde ne köyler, ne memleketler var be!" diyerek hayıflanır. Bazen de kendinin "Ön planda yemyeşil bir çayır var, çiçeklerle donanmış" (Kutlu, 2016: 144) resimdeki köyde olduğunu hayal eder. Burada şehir-köy zitlığı ve köyün güzelliği çiçeğin anlam değeri üzerinden aktarilır.

"Allah Bes!" hikâyesinde ise kocası Yaşar'ı bırakıp evden ayrılan Fatma, eşinin ısrarıyla ve kendisine sürprizi olduğu yönündeki sözleriyle evine geri döner. Çiftin bu dönüşlerinden sonra daha mutlu ve huzurlu bir yuvaları olur. Oğulları Ömer yürümeye başlar. Anlatıcı, ailenin bu mutluluk tablosunu "Fatma evi terk etmeden 
önce bir teneke kutuya dikerek pencere önüne koyduğu camgüzelinin bir sabah sessizce açtığını gördü. İçi pır pır etti. Gidip parmağının ucu ile çiçeğe dokundu. Bu ufacık çiçeğin kırmızıya çalan pembesi bütün evi ışı̆̆a boğmuştu. Allah bes" (Kutlu, 2016:167) cümleleriyle aktarır. Burada ailenin saadete erişmesi çiçek imgesi üzerinden anlatılarak çiçeğin açması, canlanması ailenin mutlu ve huzurlu olmasıyla özdeştirilir.

\section{SONUÇ}

Türk hikâyeciliğginin seçkin kalemlerinden biri olan Mustafa Kutlu, hemen hemen her eserinde kuş ve çiçekle ilgili kullanımlara çeşitli vesilelerle yer vermiştir. Kutlu'nun eserlerindeki zengin imgelem dünyasında kuşlar ve çiçekler başat varlıklar olarak öne çıkmaktadır. Yazarın kısa hikâyelerini ihtiva eden Hayat Güzeldir eserindeki hikâyelerin birçoğunda da doğrudan ve dolaylı olarak kuş ve çiçekle ilgili imgelere, temsillere, metafor ve motiflere yer verilmiştir. Yazar, özellikle hayatın güzelliklerini yansıtma noktasında kuşları ve çiçekleri bir gösterge olarak öne çıkarmıştır. Hikâyelerde yeryüzünde, gök kubbe altında yaşayan insanlar kendisinden başka canlıların, varlıkların yaşadığını/bulunduğunu kuş ve çiçek aracılığıyla fark ederler. Gözünü tabiata, diş dünyaya çeviren kahramanlar, burada çeşitli kuşların civıltılı seslerini işitirler. Bahçelerin, korulukların, çalıların arasından çiçeklerin tatlı esintilerini, kokularını hissederler. Evlerinde, aile yaşantılarındaki huzursuzluktan, mutsuzluktan kuşlar ve çiçekler vasıtasıyla uzaklaşırlar. Üzerinde, başucunda martıların, güvercinlerin uçtuğuna sevinerek çiçek ve gül kokulu odalarında, evlerinde uyurlar.

Kitaptaki hikâyelerde, kuşlar ve çiçekler üzerinden tabiatın canlılığına, hayatın güzelliğine dikkat çekilir. İnsan yaşamını estetize eden bu varlıklarla aynı zamanda tabiattaki uyuma, sessizliğe ve sürekliliğe gönderme yapılır. Yazar da tıpkı insanlar gibi çiçekler ve kuşların da yaratıcının çizdiği kaderi yaşadıklarına inanmaktadır. Dünyada da bu varlıkların bir hakları, rolleri olduğunu ve hiçbir şeyin rastlantı olmadığını düşünmektedir. Bu iki varlıkla ilgili imgeler ve temsiller üzerinden okura (insana) yaşanılan dünyanın güzelliklerini fark etmeleri için bir mesaj verir. Dünyada her şey değerlidir, asıl olması gereken bu değerleri görmek, fark etmek ve duymaktır. Yazar, kuş ve çiçek imgeleriyle insanların dünyanın ritmini bozmasını, hayatı çekilmez kılmasını, tabiata zarar vermesini, anlamsız ve özensiz yaşam biçimini eleştirir. Modern bireyin tabiat karşısındaki duyarsızlığına, hayvanlara karşı sevgisizliğine, çiçeklerin diline vakıf olamayışına üzülür. Bu varlıkları insanın kendisini keşfetmesi, tabiata ve dolayısıyla hayata dair güzellikleri fark etmesi bağlamında imgesel düzlemde işler. Kuşlardan, çiçeklerden uzak kalmak insanı yaşadığı dünyaya yabancılaştırır ve mutsuz kılar. Bu ayrılık bireyi kendi yalnızlığına iter; böylelikle hayat da güzelliklerini bir bir yitirir. Kitapta kuşlar ve çiçekler sembolik anlamda insan hayatını kıymetli kılan, yaşadığı çağda hayata tutunmasını sağlayan ve güzellikleri yansitan bir olguya dönüştürülerek verilir. Bu eserinden hareketle Kutlu'nun hikâyelerinde kuş ve çiçek imgelerinin ve temsillerini yazarın kaleminde güçlü bir şekilde belirdiğini söylemek mümkündür. Bu yönüyle özgün bir hikâyeci olarak Kutlu, tabiatın çeşitli biçimlerini sunarken, hayattaki canlıları, varlıkları, olayları tutkuyla ve

| Sosyal Bilimler Araştırmaları Dergisi 
sevgi diliyle okuruna aktarır. Kuş ve çiçek de bu aktarıma imkân sağlayan, imgelem ve temsil gücüne sahip iki öğe olarak değerlendirilebilir.

\section{KAYNAKÇA}

Abasıyanık, S. F. (2002). Son Kuşlar, İstanbul: Yapı Kredi Yayınları.

Ali, S. (2016). Değirmen, İstanbul: Yapı KrediYayınları.

Atasü, E. (2003). İmgelerin İzi, İstanbul: Can Yayınları.

Aydın Özer, E (2014). “Orhan Veli' de Öykü, Sait Faik'te Şiir”, Türk Dili, S. 107, s. 143150.

Ayvazoğlu, B. (1997). Güller Kitabı, İstanbul: Ötüken Yayınevi.

Batur, E. (2000). Başkalaşımlar, I-X, X-XX, İstanbul: Yapı Kredi Yayınları.

Boynukara H. (1997). Modern Eleştiri Terimleri, İstanbul: Boğaziçi Yayınları.

Burnett, R. (2012). İmgeler Nasıl Dü̧̈ünür?, (Çev. G. Pusar), 2. Baskı, İstanbul: Metis Yayınları.

Cevizci, A. (2000). Felsefe Sözlüğ̈̈, İstanbul: Paradigma Yayınları.

Demiralp, O. (2004). “İmaj Değil, İmge” Kitaplık, S. 74, s. 75.

Friedman, N. (2004). "İmge”, (Çev. K. Atakay), Kitaplık, S. 74, s. 80-89.

Kaplan, M. (1997). Hikâye Tahlilleri, (6. Baskı), İstanbul: Dergâh Yayınları.

Korkmaz, R. (2002). İkaros'un Yeni Yüzü Cahit Sıtkı Tarancı, Ankara: Akçağ Yayınları.

Kutlu, M. (1999). “Kuş Sesleri”, Yeni Şafak, 24 Şubat.

Kutlu, M. (2016). Hayat Güzeldir, (10. Bask1), İstanbul: Dergâh Yayınları.

Kutlu, M. (2016). Yoksulluk İçimizde, (19. Baskı), İstanbul: Dergâh Yayınları.

Lekesiz, Ö. (2001). Yeni Türk Edebiyatında Öykü 4, İstanbul: Kaknüs Yayınları.

Leppert, R. (2009). "Sanatta Anlamın Görüntüsü E İmgelerin Toplumsal İşlevi", (Çev. İ.

Türkmen), 2. Baskı, İstanbul: Ayrıntı Yayınları

Özdenören R. (2011), Yazı, İmge ve Gerçeklik, 3. Baskı, İstanbul: İz Yayıncılık.

Ponty, M. M. (2012). Göz ve Tin, (Çev. A. Sosyal), İstanbul: Metis Yayınları.

Ponty, M. M. (2010). Algılanan Dünya, (Çev. Ö. Aygün), İstanbul: Metis Yayınları.

Sartre, J. P. (2009). İmgelem, (Çev. A. Tümertekin), 2. Baskı, İstanbul: İthaki Yayınları.

Şakar, C. (2012). İmge, Gerçeklik ve Kültürr, İstanbul: Onur Kitaplığ1.

Türk Dil Kurumu (2011). Türkçe Sözlük, 11. Baskı, Ankara: TDK Yayınları.

Timuçin, A. (2003). Estetik, İstanbul: Bulut Yayınları.

Tosun, N. (1999). Hayat ve Öykü, Ankara: Hece Yayınları.

Tosun, N. (2004). Türk Öykücülüğ̈̈nde Mustafa Kutlu, İstanbul: Dergâh Yayınları.

Yıldırım, E (2007). Mustafa Kutlu Hikâyeciliği, Ankara: Ebabil Yayınları.

Yılmaz, E. B. (2011). “Hikâye ve Romanlarda Sembol Dilinin Görüntüleri Üzerine Bir Değerlendirme", Bilig, S. 56, s. 45-56.

Yücel, H. (2013). İmgeden Yoruma, İstanbul: Ayrıntı Yayınları. 